International Journal of Business and Management Review

Vol.9, No.2, pp.22-48, 2021

Print ISSN: 2052-6393(Print),

Online ISSN: 2052-6407(Online)

\title{
CULTURAL FACTORS INFLUENCING PSYCHOLOGICAL CONTRACT (PC) EXPERIENCES AMONG SURVIVOR MANAGERS
}

\author{
Sunday C. Eze \\ Department of Business Studies, Landmark University, Nigeria \\ sundayeze2010@gmail.com \\ Christian Uchendu \\ University of Bedfordshire \\ Vera C. Chinedu- Eze \\ Department of Agric Business, Michael Okpara, Unievsrity of Agriculture, Umudike,Nigeria \\ veradezy1@gmail.com
}

\begin{abstract}
Most researches on psychological contract are conducted in the banking sector while limited local enquiries focused on the experiences of the survivor-managers in developing economy particularly in Nigeria. This study therefore, examines the cultural factors influencing PC experiences and responses among survivor-managers in Nigeria. The study adopted a qualitative approach and more specifically interviews. Data were analysed using empirically driven thematic analysis. The findings revealed that; unemployment, values of dependency, corruption, family obligations, beliefs, spirituality among others shape attitudes and responses of the survivor-managers' with respect to downsizing exercise. Therefore, human resource managers who are part of the downsizing exercise should embrace open and transparent process as well as being sensitive to the wellbeing of the victims and survivors to reduce the negative psychological contract experiences and responses among Survivormanagers. In addition, the research created awareness on the need to diversify research in terms of methods adopted.
\end{abstract}

KEYWORDS: Culture, psychological contract, Survivor-managers, developing economy, Nigeria

\section{INTRODUCTION}

Studies on psychological contract (PC) has gained momentum in the last few decades (Restubog et al 2008) owing to rapid increase in organizations' activities such as downsizing, restructuring, and their effects on work relations (Chaudhry et al., 2011). Studies (e.g Shore et al., 2004; Chaudhry et al 2011; Pansera and Owen 2018; Chang 2018; Coyle-Shapiro et al., 2019) have shown that there is a link between employment relationship and PC during downsizing in organizations because several change programmes most times lead to reduction of the workforce. Both the victims (those whose employment was terminated) and those who survived the exercise often consider the actions of the organization as breach to the contract terms and obligations. Despite that, studies revealed that the major reason organizations go through downsizing is due to unstable environment of the business (Datta et al., 2010) however, the victims and the survivor-employees have been affected psychologically, financially, socially (see; Restubog et al 2006; Davis-Peccoud et al 2016; Cascio and Young 2003); and 
evidences have shown that enormous studies have been carried out mostly in developed countries on such issue.

Psychological Contract is the opinion both the employers and the employees hold about their social relationship. This opinion is based on the employee's expectation and the organization's responsibilities, rights, privileges, and how these shape their work relationship (Cullinane and Dundone 2006). It is a concept that aids the understanding of work relationships (Zhao et al 2007; Fortune 2018). PC is an exercise that assists individuals or people to comprehend employment relationships (Rousseau 1989). This exercise is depended on supposed promises made to employees via discussions and practices (Thomas et al 2003). PC which is viewed as implicit and unspoken expectations in work relationship is ever-changing because of the paradigm shift from the conventional employment relationship due to the emerging and complex nature of the organizational environment (Cullinane and Dundon 2006; Dixon-Fowler et al 2013; Fortune 2018) to suit the changing market situations and the parties involved in the exchange agreement process. These parties may deliberately or accidentally fail to come to terms with the agreement because they were unable to understand the conditions. In situations where none of the parties meet the conditions or obligations, it is referred to as breach (Rousseau 1995; Tekleab and Taylor 2003; Omoruyi et al 2011; Huzaifah bin Magbool et al 2016) and employees most times respond undesirably when they experience breach.

PC has generated a lot of attentions (Restubog et al 2008), most research works on psychological contract experiences concentrated more on those that have been laid off (Sronce and McKinley 2006; Jones et al 2016; Coyle-Shapiro et al 2019), compared to the survivors despite the vital roles played by the survivors in psychological contract formation and execution (Rousseau 1998). In addition, studies have investigated the effects of downsizing in various capacities as it affect employees and the organizations. However, majority are conducted in the banking sector (Samuel et al 2009) and in the western context. Blunt and Jones (1992) have argued that findings associated with the organizational problems in the western context may not fully explain such problems in developing countries because of the dissimilarities in culture especially when such is linked to individual beliefs and experiences during organizational downsizing. There is still dearth of local scholarship that has focused on the cultural factors shaping the psychological contract experiences by the survivor-managerial group, (Gandolfi 2008, Chang 2018, Chen et al 2008) particularly in developing economies(Rousseau and Schalk 2000) like Nigeria. unarguably, substantial number of research studies (e.g Clair and Dufresne 2004; Sparrow 1998; Gandalf 2007) have argued that the implementers of these change management programmes may have suffered from same psychological and emotional trauma as victims, research on this set of individuals has always been ignored(Chang 2018). Therefore, this study explores the cultural factors shaping the psychological contract experiences by the survivor-managerial group since these set of people are likely to respond to change in dissimilar ways (Thomas et al 2003; Adams et al 2016). This paper is structured as follows: First, it reviews and analyses the literature; secondly, it presents the research approach and data analysis process; thirdly, it presents and highlights the findings; while the last section highlights, discusses, concludes, presents the implications, notifies the limitations and recommends for further (future) researches on the study to widen its scope. 


\section{LITERATURE REVIEW}

\section{Downsizing as a Change management approach}

According to Cullinane and Dundon (2006) organisational change is a cautious attempt by an organisation to introduce a unique way of thinking that would help accomplish certain goals and objectives of the organisation. This is fast becoming a norm and a survival strategy for many organisations. The agreement by management to adopt a new way of thinking and accomplishing tasks or goals are based on constant pressure on competition and cheaper costs. (Cullinane and Dundon 2006). This has led to both assurances to job security and the satisfaction that the individual derives from career choices less sustainable. On the other hand, other studies (Guest and Conway 2002b; Godard 2004; Data et al 2010; Chang 2018) have attributed to such change to market pressures, new approach to governance, systematic rationalisation, economic model liberal market, downsizing as well as deregulations. These findings are in line with Zhao et al (2007)'s study which argues that major changes take place in the organisation's arrangement for downsizing such as layoffs and have affected the sensitivities and relationships with the employees. Although change is the most common word used by business managers, it has become vital to the survival of most organisations. However, it is the way organisations adopt or carry out such change that results to breach of psychological contract perceived by the employees (Knights and Kennedy 2005). Such breach is often referred to as management parlance as downsizing; or right-sizing, de-layering and restructuring. These activities carried out by organisations often lead to a change in organisational efficiency and employment relationships (Sparrow and Cooper 1998; Delery and Roumpi 2017; Diaz-Fernandez et al 2017).

Organisational "downsizing" is the deliberate reduction in the number of employees in a bid to cut cost. It is conducted when there is deficiency in operation resulting to less productivity. It is done to balance labour capacity and labour cost. In this study, the researchers see downsizing as a deliberate restructuring exercise or strategy conducted by management to reduce organizational size and operating cost to appropriate size thereby improve performance and productivity which results to change in work processes in the organization. Downsizing is linked to job losses, anxiety, lack of commitment on employees in Nigeria (see Omoruyi et al 2011 and Samuel et al 2009). Different theories have emerged on the strategic concepts of downsizing. Drawing from Sparrow and Cooper (1998) the adoption of downsizing by organisations is dependent on socio-cognitive, institutional and economic perspectives. The economic perspective considered downsizing as a response to decline in productivity and profitability (Sparrow and Cooper 1998; Ehnert and Brandl 2013; Diaz-Fernandez et al 2017) in the organisation while the institutional theorists stressed that downsizing is embarked in organisations because of good management and social resolution (Yu and Park 2006; CoyleShapiro et al 2019). However, the benefits of this change strategy have been debated considering the degree at which downsizing impacts on job losses, mass layoff, unemployment and breach as a result of the implementation (Datta et al 2010; Longoni 2014; Sanz-Valle and Jimenez 2018). These often reduced loyalty, mistrust; increase in the level of turnover intentions; decline in the organisational commitment as well as separation anxiety, declined in innovation and job involvement, loss of skills and knowledge (Trevor and Nyberg, 2008; Zhao et al 2007; Suazo 2009; Shipton et al 2017). These negative consequences often linked to the psychological contract breaches. 
Downsizing has led to significant disorder in an organisation. This has impacted both the workforce and the organisation negatively (Amiot et al 2006; Cartwright 2008; Delery and Roumpi 2017; Diaz-Fernandez et al 2017). Although the concept was first adopted by the US firms because of the competition from Japan (Budros 1999; Sollosy et al 2015 ), it has been globally acknowledged and accepted as a change process in the western world (VicenteLorente and Suarez- Gonzalez 2007), developing and emerging economies. However, a study (Lindorff et al 2011)shows that such changes are without its consequences for both the employees and organisation with a failure rate of about 70 per cent (Washington and Hacker 2005; Burnes 2000). Downsizing (Lester, Kickul and Bergmann 2007; Tang et al 2015) reduces the performance level of individuals which leads to a decline in the organisational performance (Lester, Turnley, Bloodgood and Bolino 2002; Wright and Ulrich 2017), poor employment association and a breach to psychological contract. Munoz-Bullon and Sanchez-Bueno (2011) have investigated on change process such as downsizing, however, their findings reveal that organisations should endeavour to manage downsizing effectively to avoid the negative effects on employees (Hitt et al 1994; Perssona and Wasieleski 2019). Raja et al (2004) and Zhao et al (2007) note that often one major mistake made regularly is overlooking such negative effects of on employees including those that are retained after downsizing. The literature revealed that organisational downsizing may hurt survivor employees, and it is imperative to understand the psychological and emotional impact on survivor wellbeing. Hence, this necessitated the study especially in a developing country such as Nigeria.

\section{A Model of Cultural Influence}

This research proposes national culture or how the beliefs, norms, attitude and values in a society (Lytle et al 1995; Thomas et al 2010) shapes how individuals view, manage and exchange relationship with their employers (Thomas et al 2010). Although, Sahay and Walsham (1997) noted that individual, societal and organisational level attributes, shape the method a psychological contract will take (Rousseau 1995; Raja et al 2004), the main focus of the study is to explore the individual-level mechanisms through which a culture of an individual shapes the psychological contract. According to Thomas et al (2003) and Thomas et al (2010), individuals are rooted in a particular national culture and embrace the profiles of such cultures. These profiles are often affected via individual-level cognitive and motivational mechanisms (Thomas et al 2010).

The cognitive perspective is of the view that mental comprehension of an individual affects how the individual process information regarding situations such as their relationships with their employers in their organization. This entails that an employee's culture can significantly affect their relationship with their employer. Variation in culture influences perception and interpretation of signals from the organization with regard to the psychological contract. Individuals from different cultures learn different sets of values (Erez and Earley 1993), which develop into cognitive frameworks (schemas) used to help, organize and process information (Fiske and Taylor 1984; Pelled and Xin 2000; Thomas et al 2010). Priorities differ according to values attached to them. The value attached to each priority determines the response and attention given to them which are formed by gradually internalizing prevailing cultural patterns (Markus and Kitayama 1991; Miller et al 1990). Research indicates that both perceptions of 
events (e.g. Bagby 1957) and ascription made about their causes (Ting-Toomey 1988) vary across cultures.

Secondly, from the motivational perspective, social exchanges between individuals and their organizations are fundamentally tied to how people view (Thomas et al 2010) themselves and their relationships to others as well as their motivation. This social exchange reveals the costbenefit analysis of the relationship between an employee and his employer. Psychological contract can be breached if the risks outweigh the benefits of the relationship. The self-concept acts as an information processor that selects, interprets and evaluates the meaning of action through its contribution to personal self-worth and well-being (Erez and Earley 1993). It is worthy to note that employees strive to maintain a positive self-image wherever they find themselves. However, what constitutes a positive self-view depends on how the self is construed. People in different cultures exhibit different conceptions of self and interdependency with others (Markus and Kitayama 1991). Individuals seek to fulfil motives aligned with their differing cultural values. In the motivational domain, culturally different selfconcepts influence what is desirable with regard to exchange relationships with employers. Together, these mechanisms help to explain the mechanics of cultural influence. However, this study focuses on the cognitive perspective as it affects Nigeria.

\section{Cultural influence on psychological contract (PC)}

The emergence of globalisation and continuous downsizing practice has changed the way organisations carry out their operations. This has made the study of cultural dissimilarities and organisation workforce a significant area of research. This is because PC is a mental schema, and the way it is understood and interpreted depends on personal perceptions, cultural orientations and belief (Rousseau 1989). Thomas et al (2003) is of the view that a person's cultural variances shape its cognition of the PC development and violation and this affects the way the person responds to such violations. Also, national and cultural values shape individual's views and decisions and this, in turn, shape the way such individual react to situations or events (Westwood et al 2010). Because of the nature of diverse cultural backgrounds associated with these individuals, such individuals are likely to observe, act and comprehend workplace events differently during the change process. In a similar vein, Dadi's (2012) work revealed that cultural obligations, as well as the extended family structure, shaped the PC experience of the black workforce in the UK. Although early conceptualization of PC stresses the influence of culture, a substantial number of recent research works has ignored this (see Thomas et al 2003; Chang 2018).

Culture is a mental programming associated with knowledge and experience and differentiates a group in a particular society or nation from another. It is people's way of life which ranges from the manner they handle, solve or settle problems (Akporherhe 2002; Hofstede 1983, 2001; Kessapidou and Varsakelis 2002; Diaz-Fernandez et al 2017). Empirical evidence has shown that cultural differences account for the disparity in individual view and understanding of PC (Dadi 2012). According to Dadi (2012), culture influences the way people interpret and view exchange agreements and several studies have explored the concepts such as perception, behaviour and emotions and have argued that cultural responsibilities are psychological. Hence, the way of life of particular society are entrenched in such individuals living within the 
society and such individuals move with such norms and values as they are employed in an organization (Olurode 1994; Dadi 2012; Delery and Roumpi 2017). Therefore, an employee must always review and situates his/her cultural responsibilities with that of the organizational duties for a smooth and continual PC experience.

Furthermore, Rousseau and Schalk (2000) noted that education institutions and family system shapes different values and behaviours. In Nigeria, people are part of their extended families, and such individuals are expected to resemble their ancestral lineage. The actions of such people are expected to be in line with the larger family beliefs, norms, and values. Triandis (1995) is of the view that culture is linked to psychology and shared values of social group play important role in one's social functioning, cognitive and emotion which may be different in a more developed or western world. Therefore, the variances in peoples' culture may shape how they identify, perceive, and breach behavioural responses (Thomas et al 2003; Ehnert and Brandl 2013). Arguably, the psychology of a person or individual may shape the way the individual behaves when there is a perceived PC breach. The implication of this is that values and beliefs of one's culture may likely shape the survivors' behaviour in an organisation.

\section{Survivors' experience and perceived PC breach}

Previous studies (see Sahdev 2003; Bujang and Sani 2010; Yu and Park 2006; Coyle-Shapiro et al 2019) have argued that survivors are most likely to experience psychological and emotional shock after a downsizing exercise which is often known as 'survivor syndrome' (Noer 1993), which is defined as different emotional and attitudinal behaviour displayed by employees who survived downsizing exercise (Littler et al 1997; Longoni 2014; Sanz-Valle and Jimenez 2018). A Survivor is an employee who was fortunate to have retained his/or job after a restructuring exercise had been carried out. Noer (1993) found that survivors during downsizing experienced negative feelings such as job insecurity, job insecurity, depression, anxiety, unfairness, and these have a negative impact on their social relationship both at work and home (Noer 1993; Bujang and Sani 2010; Farewell 2007). While some studies (e.g Bujang and Sani 2010; Longoni 2014) are of the view that what survivors' experience during downsizing are more negative than positive, others argue that such syndrome does not manifest (Sanz-Valle and Jimenez 2018). However, survivors may respond to these experiences in different ways depending on the extent of the impacts and experiences

According to Morrison and Robinson (1997), the responses of survivor's are different from one person to another due to distinct beliefs and expectations. These responses can be constructive or destructive (Mishra and Spreitzer 1997). The constructive response is associated with survivors that tend to cooperate with management, support change objectives while the destructive response is linked to survivors who are not willing to cooperate during the implementation of any change programme and may ignore taking part in any extra job roles. Although different survivor responses identified may be linked to works carried out in western culture (Spreitzer 199), however, how survivors respond to psychological experiences differs because of differences in culture (Sahdev 2003). Therefore, focusing this study in Nigeria may assist human resources (HR) practices for an efficient restructuring and reduce the challenges faced by HR Managers. 
Human resource management (HRM) practice and the causes of restructuring in Nigeria Although HR was introduced in the Nigeria literature in 1940s (Fajana et al 2011; Delery and Roumpi 2017), the way and manner in which HRM was practised in Nigeria is still pathetic. HRM in the most developing economy today was adapted from Anglo-American and grounded on cultural and institutional influences(Kamoche 1997), and it is still at its infancy( Fajana 2009). According to Hofstede (1993), the policies and practices of HRM are often shaped by culture, social and economic environment. In Nigeria, the challenges faced by HRM are many and they include federal character principle, lack of specialization and professionalism, educational qualification and lack of integrity on promotion exercise (Fajana et al 2011; DiazFernandez et al 2017). Besides ethnicity factor such as fear of control amongst the different nationalities in Nigeria, the implementation of global change management strategy such as downsizing and complexity in the human capital resource (Fajana et al 2011).

Since the birth of Nigeria in 1960, the country has experienced so many structural, political and economic vicissitudes in a bid for repositioning. The nation is gifted with huge natural and human resources and was ranked 6th and 8th in the world in terms of gas and oil reserves with a population of about 200 million(Sanusi 2011). Despite the enormous amount of human and natural resources, the country has failed regardless of the huge natural endowments. The reasons associated with the failure include political instability, continuous military interventions and institutionalized corrupt practices and economic maladministration. In a bid to tackle these issues, the succeeding government have introduced programs to ensure that the economy is stable. These reforms include 2002/2003 and 2004/2005 banking reforms (Sanusi 2011) aimed at improving the economic growth which majorly focused on the financial sector. This reform in particular led to investment and growth of the Nigerian capital market (Sanusi 2011; Sollosy et al 2015).

However, the Nigerian equity market nearly crashed due to the recession of 2008 (CBN 2009). The crash was linked to the poor practice by the government, corruption by bank CEOs and deceitful managements (CBN 2010). This led to massive restructuring, redundancies, layoffs and downsizing particularly in the financial sector such as banks and equity markets. This exercise resulted to joblessness and poverty in most families because most families are dependent on a single breadwinner of the family (Kamoche 2002). This is because Nigerians are known for sharing and they play a big part in supporting family members who are dependent in times of need. According to Hofstede (1983), this way of life is referred to as collectivists. However, despite the importance of this study in less developed nations like Nigeria, dominant research literature in the western context are homogeneous in nature while in developing nations such works are ignored(Kamoche 2000, 2002) in Nigeria.

\section{METHODS}

According to Coyne (2008) understanding complex human emotional and psychological issues could best be undertaken through a qualitative approach hence this research adopted a qualitative method. Also, the qualitative research method is flexible and the inductive nature of it provides a good platform to explore the individual and the internal psychological process such as the feeling of psychological breach and emotion (Guest et al 2013). The study also adopted a purposive sampling technique which is based on the purpose of the research (Schwandt 1997) and aims at identifying the participants and their real-life experiences 
(Woodgate 2006). The researchers adopted this technique because qualitative is subjective and not for statistical generalisation (DiCicco-Bloom and Crabtree 2006). This technique also helps for a realistic comparison of participants (Mason 1996). It is important to note that the unit of analysis is individually based (survivor managers), and this assisted in achieving the objectives of the study due to the close interaction with the participants (Lincoln and Guba 1985; Creswell 2003).

The research was conducted in Lagos because Lagos state is a multicultural town in Nigeria and has about 20 million people as its population. There are about 175 companies that are associated with the capital market sector, and out of this number 80 per cent of them are in Lagos (www.nairaland.com), and the researchers had easy access to the interviewees. The participants that took part in the interview were drawn from the Nigerian online business forum and the capital market regulation commission website. These assisted the researchers in categorising those operators within the sector that have embarked on the downsizing program in the last 3 years. Many of the stock broking firms where the participants were selected have staff ranging between 25 and 150 and are categorised as SMEs. 60 participants were selected purposefully from the 25 stock broking firms and out of this number, 20 survivor managers were interviewed. Semi-structured interview approach was used to collect the data from the 20 survivor managers. Before the interviews were conducted, the researchers sent out a formal letter to the participants. The formal letter contains the aim, objectives of the research, rights, responsibilities and obligations of the researchers.

\section{Interviews}

First, a pilot interview was conducted to provide a clear understanding of the subject matter under investigation. The researchers selected the participants for the interview based on the fact that they must be first-line managers; these managers must have experienced downsizing exercise in their organisation. The researchers developed a guide for the interview to reflect the questions in line with the objective. The purpose of the interview was explained to the participants after whom consent forms were given to them to sign before the interview commenced. At the initial stage, seven (7) participants purposefully drawn from 4 out of the 20 firms selected were interviewed using unstructured interview questions. All the interview sessions at this stage lasted for about an hour. Probe questions were further asked to elicit deeper meaning depending on the themes that were constantly emerging during the interview. Themes that emerged at the initial stage formed the basis for the development of the semistructured interview questions.

At the second stage, semi-structured interview guides or questions were designed and reviewed before it was used. It is important to note that before the interviews, formal letters were sent to the participants who agreed to be interviewed detailing and describing the research purpose and the confidentiality related issues. The researchers interviewed thirteen (13) participants at this stage and all interviews lasted for about an hour. Both the pilot interview and semistructured interviews helped to ensure that the research objectives were achieved. Table 1 below shows the number of participants, names used for coding the data in each organisation. 
Table 1: Company profile

\begin{tabular}{|c|c|c|c|}
\hline $\begin{array}{c}\text { No of } \\
\text { participants }\end{array}$ & Participants & Role & Staff strength \\
\hline 3 & $\begin{array}{l}\text { RA } \\
\text { RB } \\
\text { RC }\end{array}$ & stockbroking & 135 \\
\hline 2 & $\begin{array}{l}\mathrm{RD} \\
\mathrm{RE}\end{array}$ & stockbroking & 50 \\
\hline 1 & $\mathrm{RF}$ & stockbroking & 120 \\
\hline 1 & RG & stockbroking & 75 \\
\hline 2 & $\begin{array}{l}\text { RH } \\
\text { RI }\end{array}$ & stockbroking & 80 \\
\hline 3 & $\begin{array}{l}\text { RJ } \\
\text { RK } \\
\text { RL } \\
\end{array}$ & stockbroking & 35 \\
\hline 1 & $\mathrm{RM}$ & stockbroking & 78 \\
\hline 1 & RO & stockbroking & 55 \\
\hline 1 & $\mathrm{RP}$ & stockbroking & 22 \\
\hline 1 & RQ & stockbroking & 109 \\
\hline 1 & RR & stockbroking & 135 \\
\hline 1 & $\mathrm{RS}$ & stockbroking & 140 \\
\hline 2 & $\begin{array}{l}\mathrm{RT} \\
\mathrm{RU} \\
\end{array}$ & stockbroking & 105 \\
\hline Total $=20$ & & & \\
\hline
\end{tabular}

\section{DATA ANALYSIS}

Thematic data analysis was used in this study. Basically, the researchers adopted an inductive thematic data analysis approach because the codes adopted for the research were data-driven. The data analysis process adopted for the study which is presented in Figure 1 below is explained below:

In Stages land 2: The codes used for this study which emerged from the raw data during preliminary investigation formed the bases for exploring the raw data. At this stage the definitions and description of these codes were written in simpler form using a code name, the definition of the codes and how to identify themes associated with each code. These became the bases for categorizing the raw data.

Stage 3: To ensure that the codes generated empirically would apply to the raw data, in Stage 2, 7 transcribed interviews at the first stage of the research were analyses and coded manually 
into post defined categories. Following the preliminary coding exercise of the first round of the interviews, 4 judges who are colleagues were contacted through writing were the codes and supporting evidence were presented to them to relate to codes to the categories to ascertain their reliability. 2 of these judges were professors at the university level and they have conducted research using similar approach, while the other 2 judges who were also university teachers but are unfamiliar with the research were also invited via written to code portions of the data. This approach was adopted to ensure the agreements of all the four judges are same with one another. This was ascertained using inter coder agreement percentages (Gioia et al 2013). According to Gioia et al (2013), this is vital because it help provide the requisite rigor to the analysis.

Stage 4: At this stage, all the raw data transcribed either from the unstructured or semistructured interview were imported into NVivo. NVIVO is software used in qualitative data analysis. NVivo software was adopted to facilitate the analysis because of the huge data involved. This aid the easy analysis and management of the huge data transcribed.

Stage 5: At this stage, data were retrieved from NVivo and were empirically clustered (see Table 5) into appropriate categories

Stage 6: Since verification in qualitative research is always an ongoing process at stage 6, this means that other reliability and validity checks which extend to presenting the codes and quotes to the initially judges contacted to compared the entire quotes against the codes. Inter-ratter reliability of the entire data coded using percentage agreement (Boyatzis 1998) was further carried out were these judges rated the quotes against the codes and themes that emerge. This approach often requires absent or present judgments by the coders. The reliability analysis for the scope of the study shown in Table 2 in the appendix revealed over 70 per cent which suppressed the 70 per cent benchmark by Miles and Huberman (1994).

Stage 7: Validated codes were further analysed and interpreted. The data analysis process in Figure 2 below is part of the research design which reveals how data were analysed, verified and reported 


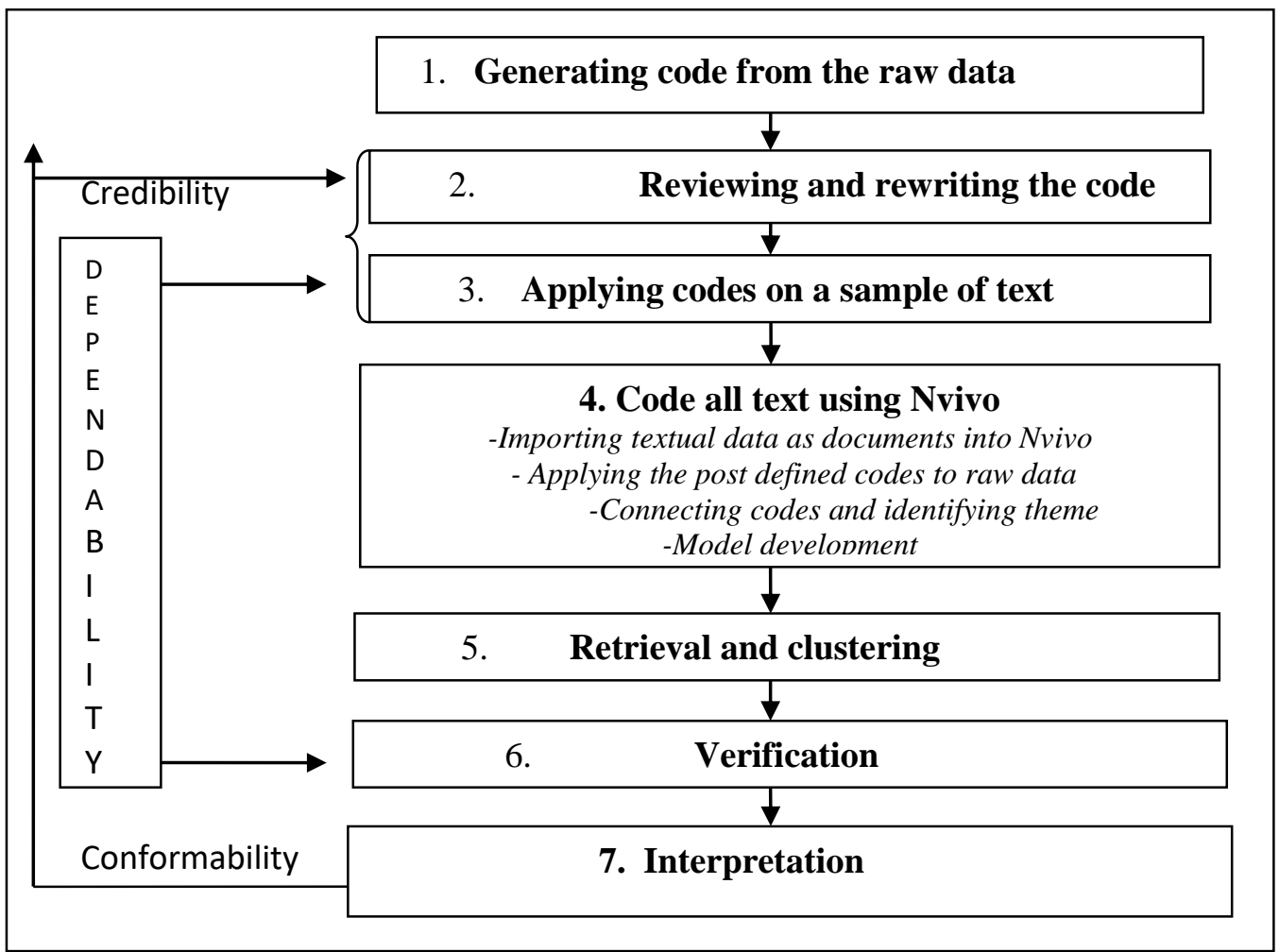

Figure 1: Data analysis process

Table 2: Reliability analysis

\begin{tabular}{|c|c|c|c|}
\hline \multirow{2}{*}{$\begin{array}{l}\text { Cultural Factors } \\
\text { Influencing Psychological } \\
\text { Contract Experiences and } \\
\text { Responses among } \\
\text { Survivor-managers }\end{array}$} & \multirow{2}{*}{$\begin{array}{l}\text { Number of } \\
\text { judges }\end{array}$} & \multicolumn{2}{|c|}{ Reliability } \\
\hline & & First two judge & Second two judge \\
\hline & 4 & $0.89(89 \%), 0.80(80 \%)$ & $0.79(79 \%), 0.86(86 \%)$ \\
\hline
\end{tabular}

\section{DATA PRESENTATION}

Tables 3 and 4 depict codes, pieces of some supporting cases and supporting evidence. Themes were generated and clustered based on the codes and patterns they emerged in the data (Boyatzis 1998). 
Table 3: Codes and sample supporting cases

\begin{tabular}{|c|c|c|}
\hline Codes & Related cases & $\begin{array}{l}\text { No of } \\
\text { Cases } \\
\text { Coded }\end{array}$ \\
\hline $\begin{array}{l}\text { Extended family } \\
\text { obligations }\end{array}$ & $\begin{array}{l}\text { RD, RE, RF, RG, RH, RI, RJ, RK, RL RM, RO, } \\
\text { RS }\end{array}$ & $\begin{array}{l}12 / 20 \\
(60 \%)\end{array}$ \\
\hline Values of dependency & $\begin{array}{l}\text { RA, RB, RC, RH, RJ, RN, RO, RP, RQ, RR, RS, } \\
\text { RT, RU }\end{array}$ & $\begin{array}{r}13 / 20 \\
(65 \%)\end{array}$ \\
\hline $\begin{array}{l}\text { Belief system and } \\
\text { spirituality }\end{array}$ & $\begin{array}{l}\text { RD, RE, RF, RG, RH, RI, RJ, RK, RL, RM, RO, } \\
\text { RP, }\end{array}$ & $\begin{array}{l}12 / 20 \\
(60 \%)\end{array}$ \\
\hline Faith in God & $\mathrm{RA}, \mathrm{RB}, \mathrm{RC}, \mathrm{RD}, \mathrm{RL}, \mathrm{RO}, \mathrm{RN}, \mathrm{RP}, \mathrm{RR}, \mathrm{RU}$ & $\begin{array}{l}10 / 20 \\
(50 \%)\end{array}$ \\
\hline Religious values & $\begin{array}{l}\text { RG, RH, RI, RJ, RN, RL, RM, RO, RP, RQ, RR, } \\
\text { RS, RT, RP }\end{array}$ & $\begin{array}{l}14 / 20 \\
(70 \%)\end{array}$ \\
\hline $\begin{array}{l}\text { Unemployment and } \\
\text { corruption }\end{array}$ & $\begin{array}{l}\text { RA, RB, RC, RD RH, RI, RJ, RN, RL, RM, RO, } \\
\text { RP, RQ }\end{array}$ & $\begin{array}{l}13 / 20 \\
(65 \%)\end{array}$ \\
\hline
\end{tabular}

Table 4: Codes and sample supporting evidence

\begin{tabular}{|l|l|}
\hline Codes & Supporting Pieces of evidence \\
obligations & ".... To be frank with you I have a lot of persons that depend on \\
me especially my parents because they are no longer active" \\
(RL) \\
"....it is my responsibility as the first son of my parents to take \\
care of my siblings no matter their conditions" (RO) \\
"... you know that our parents have gone a long way with us by \\
training us, therefore, it is our responsibility to return that \\
favour especially now they are getting older" (RS)
\end{tabular}




\begin{tabular}{|c|c|}
\hline & $\begin{array}{l}\text { "... some times when I feel that things are not working for me, I } \\
\text { consult him via prayers for help. This is not the first time and } \\
\text { God has been with me" (RL) } \\
\text { "..if you lack faith in God, as a Christian, it may be difficult to } \\
\text { withstand situations like this" (RR) } \\
\text { ".... when I survived this, I was even more committed to doing a } \\
\text { thing that will please God. Faith played a role in my } \\
\text { commitment" (RN) }\end{array}$ \\
\hline Religious values & $\begin{array}{l}\text { "... I must sincerely tell you that religion was a determinant } \\
\text { factors that helped mw to cope emotionally because of the } \\
\text { impacts downsizing had on me" (RH) } \\
\text { "....as a Christian I was guided and controlled not to disobey } \\
\text { the law" (RL) }\end{array}$ \\
\hline $\begin{array}{l}\text { Unemployment and } \\
\text { corruption }\end{array}$ & $\begin{array}{l}\text { "although people are seen as committed regardless of } \\
\text { whatever the situation is in Nigeria and this is based on } \\
\text { unemployment level, poverty \& spirituality" (RO) } \\
\text { "...because of the level of unemployment in Nigeria, if one } \\
\text { leaves his/her job, it may be difficult to get another job. This } \\
\text { situation alone increases pressure and anxiety" (RM) }\end{array}$ \\
\hline
\end{tabular}

\section{FINDINGS}

This section focuses on the cultural factors that shape PC experiences and responses among Survivor-managers. The findings show that both the attitudinal and behavioural responses of those that experience downsizing were shaped by several factors associated with culture. These factors are explained below.

\section{Extended family obligations}

Extended family obligations refer to the extent a family member feels that as a breadwinner of the family it is his/her obligation to take care of his immediate and extended families. Extended family obligations emerged as one of the key factors that shape the surviving managerial group experiences and responses. This was echoed by several participants across cases:

".... To be frank with you I have a lot of persons that depend on me especially my parents because they are no longer active" (RL)

“....it is my responsibility as the first son of my parents to take care of my siblings no matter their conditions" (RO)

"... you know that our parents have gone a long way with us by training us, therefore, it is our responsibility to return that favour especially now they are getting older" (RS)

The finding implies that the behaviour or attitudes one exhibits during a downsizing exercise is as a result of the extended family obligations which such individual must fulfil. Although the finding revealed that this may harm their wellbeing, the implication of this is that if such 
individuals lose their jobs they may not be able to support their family members as envisaged by the cultural norm.

\section{Values of dependency}

This culture of support and sharing among family members cuts across Nigeria. The value of dependency in this context is linked to individuals within families who are more fortunate than others within the family circle in terms of monetary and material resources and take the responsibility to provide for the family members. This statement was echoed by several participants:

"....the number of the person that depends on me as the breadwinner of my family is much; this is because I have to do it to help" (RJ)

"...We often see the need to provide for our family as the first thing to do in Nigeria across the board" (RP)

"as a man to I should be able to meet my immediate family responsibilities as well as my extended families such as parents, and other close relatives" (RS)

"Our culture permits dependency. Now that I am not laid off I will be able to provide and take care of my family" (RN)

The finding implies that there are people who are depended on the survivors. This is part of the norms and beliefs across Nigeria. It is important to note that when such values and norms are upheld, they shape employees responses and behaviours during any change management process like downsizing.

\section{Belief system and spirituality}

From the analysis, it was revealed that the capacity for the survivor managers to cope was based on their spirituality as well as their belief systems. These managers were of the view that there are certain things that befall a man which are unpleasant and are most times beyond human control as noted:

“...sometime one's religious belief matters. It is not only me but in Nigeria as a whole" (RH)

"What can one do? I leave it to God and people in this part of the world believe in the things of spirits" (RM)

“...so many things have spiritual attachment; so many people work hard and engage in prayers most times" (RP)

"... Although handwork is valued but the ultimate is God. I believe that it is God Almighty that can change situations" (RS)

The findings suggests that the level of attachment associated with spirituality and beliefs shape the survivors experiences and responses during downsizing and this may have some negative consequences. 


\section{Faith in God}

Faith in God in this context is referred to as the trust in God to overcome any spiteful circumstances. Evidence suggest that the respondents are of the view that having faith in Supreme Being aid in overcoming whatever predicaments associated with downsizing and this impacts on their responses and attitude. This was revealed by the participants:

"I have to admit that the faith I have in God was what kept me all through the period" (RO).

"...some times when I feel that things are not working for me, I consult him via prayers for help. This is not the first time and God has been with me" (RL).

"..If you lack faith in God, as a Christian, it may be difficult to withstand situations like this" $(R R)$.

"....when I survived this, I was even more committed to doing a thing that will please God. Faith played a role in my commitment" (RN)

The finding suggests that Nigerian context have enormous impact on the attitude of employees' which in turn shapes their psychological, emotional experiences and responses during downsizing.

\section{Religious values}

Religious values were significantly revealed as a key influence on the way people react to downsizing exercise in Nigeria. The religious value was considered by the participants as a key influence on employees' attitudes and responses during downsizing exercise. Religious values influence employees to see things from the positive point of view rather than the negative side since they believe that religion exhibits good virtues as well as subordination to authorities. Several participants expressed this:

"... I must sincerely tell you that religion was a determinant factor that helped me to cope emotionally because of the impacts downsizing had on me” (RH).

".... as a Christian I was guided and controlled not to disobey the law" (RL).

"To be frank with you I am not perfect but religion often shape behaviours in whatever I do. It also guides me on the way and manner I treat other people and react which when sudden events happen" (RN).

This finding implies that religious values shape the way employees react and/or respond to issues of downsizing in a developing environment like Nigeria.

\section{Unemployment and corruption}

Although Nigeria is abundantly blessed with resources, the country is infected with the high unemployment rate, poverty and endemic corruption which is evident in both the private and public sector organizations. These were revealed by the participants who emphasized that such shape their behaviours and responses during the downsizing exercise as noted: 
"although people are seen as committed regardless of whatever the situation is in Nigeria and this is based on unemployment level, poverty \& spirituality" (RO)

"...because of the level of unemployment in Nigeria, if one leaves his/her job, it may be difficult to secure another employments. This situation alone increases the level of nervousness" (RM)

"The CEO can sack anyone if the company is taken to court due to the level of corruption associated with our judiciary system and such case can last for decades " (RO)

This finding suggests that a high level of unemployment and corruption especially in developing economies like Nigeria shapes the way people react to downsizing exercise and this has negative impacts on the wellbeing of the employees.

\section{DISCUSSION}

Nigeria practices a communalist culture (Hofstede 1983, 2001; Tiwari and Lenka 2019) where most endeavours are being conducted in groups and such individual often depends on such a group for support. The communalist culture stresses caring and welfare of the group as very important part of the shared norm and members of the group who are wealthy are expected to support their immediate family, privileged neighbours and relatives. This is similar to previous studies on behavioural responses linked with communalist orientation (see Kirkman et al 2006; Mbigi 1997 and Ahiauzu 1989; Jackson 2002).

In some cultures like Nigeria, religion plays a role and has an insightful influence on individual beliefs, norms and attitudes. Byrne et al (2011) found that spiritual principles shape attitudes and behaviours including feeling and emotions via teachings. Similarly, Kim-Prieto and Diener (2009) also suggested that religions globally prescribe emotions and help to shape the feelings of the followers such as a feeling of love for other people in Christianity. The implication of this is that the religion associated with individual shapes individual attitudes.

In Nigeria, the belief systems are linked to all religious groups as well as the traditional worshippers. The belief in God to protect an individual when problems arise and the capability to regulate the final results is a communal belief. The belief that God is in charge of every situation and that everything that happens is allowed by God as long as a kind of moral, emotional and psychological stability. The implication is that people that trust in God's infinite power will be victorious despite the circumstances. Most religious institutions often teach about the values associated with a positive attitude ((Frankel and Hewitt 1994), even in the face of spiteful situations such as happiness, feeling of love and orientation towards life. Besides, people with high religious predisposition display positive emotions and attitude to the community (Nelson 2009; Agarwal et al 2017).

One of the common features of Nigerians is that they rely so much on prayer, God and Faith with diverse beliefs, traditionalists, Christians and Muslims. This is in line with what is commonly said 'it is well' which depicts hope for better tomorrow. Similarly, Day (2005) notes that individuals who are connected religiously stressed that having faith in God is an effective coping mechanism during stressful conditions such as downsizing exercise. Also, some 
religions prescribe positive behaviours including forgiveness, peace when such individual are faced with injustice as such they believe that God will take charge of the situation (Byrne et al 2011; Arshad et al 2016). The implication of this is that people that have faith in God or strong religious beliefs exhibit positive attitude and emotional constancy during organisational downsizing which might impact on such individuals negatively. Factors such as the belief system and spirituality, faith in God, and religious values shape the behaviours and responses of the managers during downsizing because religious principles aid in the emotional and psychological stability when downsizing exercise arises in the organisation. Besides, the faith that situations are time-based and that the outcomes are purely determined by God also hinders individuals from displaying negative behaviours. These findings are consistent with these past studies (see Fongwa 2002; Omonzejele 2008; Barasa et al 2017). According to Williams, Satterwhite and Saiz (1998) considered the role of religious beliefs, values, spirituality, on the opinions and behaviours of people of African origin including Nigeria and found that the behaviours of individuals may be shaped by values and beliefs.

Furthermore, regardless of the abundant natural resources, Nigeria as a nation is endowed; the country has been infested with endemic corruption, high unemployment rate leading to a high poverty rate. The corruption levels today are found among the private and public office holders and ranges from, tribalism, nepotism and graft. Unemployment is increasing day in, day out are families are struggle to survive. The corrupt practices also extend to human resource management practice in organisations were promotions and jobs are dependent on who you know in government. It was evident during the analysis that uncertainties occasioned by unemployment and a high level of corruption shape managers behaviour and responses in the face of downsizing. Similarly Bond and Smith (1996a), are of the view that culture shapes behaviours and also mediated by socio-political factors such as unemployment and corruption. This finding is consistent with the attribution theory which looked at how behavioural responses that define subjective thoughts are associated with psychological and /or external causes (Weiner 1995; Badshah 2007; Hossain 2018; Karim and Kaul 2015; Ren and Jackson 2018). Arguably, God factor, belief system, faith and spirituality, religious values, shapes the attitude and responses of the survivors' workforce in Nigeria during downsizing and other change management exercise.

\section{CONCLUSION AND IMPLICATION}

\section{Conclusion}

The study examines the cultural factors that may shape the psychological contract experiences and responses among Survivor-managers since arguably, the cultural features of an individual shapes its, behaviours, norms and attitude and responses The finding indicate that several factors: family obligations, beliefs system, values of dependency, spirituality, religious values faith in God, unemployment, family obligations and corruption. Influence survivor managers' attitudes and responses to downsizing exercise. These factors in one way or the other influence the experiences and responses among Survivor-managers but at different levels as depicted in Table 3. For instance, the extended family obligations account for $60 \%$ of the total supporting cases, values of dependency(65\%), belief system and spirituality (60\%), faith in God (50\%), 
religious values $(70 \%)$ and unemployment and corruption(65\%). These findings have some implications

\section{Implication}

Theoretically, several studies in this area have used experimentation, case study or survey method while qualitative methods that specifically implemented the inductive approach are barely used. Despite that fact that these approaches are well acceptable methods, however, adopting qualitative approach especially with the use of inductive driven approach of thematic analysis will further create awareness on the need to diversify research in terms of the methods being used. Furthermore, Macredie and Mijinyawa (2011) pointed that some research works have failed to define the theoretical concepts, and this alone has made the exploration and validation of variables difficult in studies. Therefore, the themes that were unveiled can be utilized in developing hypotheses to validate these study findings. It has been argued that an alternative approach such as the comparative studies or cross-sectional survey may be used to better validate and understand the cultural factors that may shape the psychological contract experiences and responses among Survivor-managers.

Practically, human resource managers who are part of the downsizing exercise should embrace the open and transparent process as well as being sensitive to the wellbeing of the victims and survivors to reduce the negative psychological contract experiences and responses among Survivor-managers and to ensure the attainment of the envisaged objectives of downsizing practice. Also, an open and planned meeting with the employees should be encouraged so that counselling and information support to remain employees regardless of the downsizing exercise.

Dedrick and West (2003) note that research findings are useful tools for decision-makers. These findings identified above may serve as a frame of reference for firms that want to have a clearer understanding of the factors cultural factors shaping the psychological contract experiences and responses among Survivor-managers. Furthermore, the finding may be deployed to further investigate why an organization's productivity is low (Benbasat and Moore 1992; Kurucz et al 2017). The argument on this work may be deployed by organizations as well as the empirical understanding to create awareness of the challenges encountered during the change management process.

\section{Limitations and Future Research}

A qualitative approach was used in line with the research design, collection and analysis of the data, however, the resultant effect may be unanticipated respondent -and- research bias in the analysis of the data which limit the understanding of the alternative approaches (Macredie and Mijinyawa 2011). The researchers argued that more studies should be carried out using an entirely different approach (e.g mixed-method, comparative study) to validate and confirm the findings further. Secondly, the issue of generalisability in qualitative research has also been seen as a limitation. Therefore, the generalisability of the study needs to be established across a broader population. Future researchers may adopt a confirmatory statistical approach test, validity and confirm the findings and may be used as a benchmark for constructs of psychological contract experiences and responses. 


\section{REFERENCES}

Adams, R., Jeanrenaud, S., Bessant, J., Denyer, D., and Overy, P. 2016. "Sustainabilityoriented innovation: A systematic review". International Journal of Management Reviews 18(2): 180-205.

Adegoroye, G. 2006. "Public service reforms for sustainable development: The Nigerian experience", Keynote Address at The Commonwealth Advanced Seminar, Wellington New Zealand, 20TH Feb-March $3^{\text {rd }}$.

Amiot, C. E., Terry, D. J., Jimmieson, N. L., and Callan, V. J. 2006. "A longitudinal investigation of coping processes during a merger: Implication for job satisfaction and organisational identification". Journal of Management 32(4): 552-574.

Anderson, N., and Schalk, R. 1998. "The psychological contract in retrospect and prospect". Journal of Organisational Behaviour 19(1):637-647.

Agarwal, N. K., Xu, Y., and Poo, D. C. C. 2011. "A context-based investigation into source use by information seekers". Journal of the American Society for Information Science and Technology 62(6): 1087-1104.

Agarwal, N., Grottke, M., Mishra, S., and Brem, A. 2017. "A systematic literature review of constraint-based innovations: state of the art and future perspectives". IEEE Trans. Eng. Management 64(1): 3-15. https://doi.org/10.1109/TEM.2016.2620562.

Aleksynska, M., and Berg, J. 2016. Firms' Demand for Temporary Labour in Developing Countries: Necessity or Strategy? (Geneva).

Akporherhe, F. 2002. "The challenges of English and other foreign languages on Nigeria culture". Journal of Nigerian Languages and Culture, Owerri: APN ILAC Vol. 3: 2933.

Arshad, M.A., Mahmood, A., Akhtar, S., and Ahmed, A. 2016. "Overcoming resistance of downsizing: a case study of ledzworld Technology Company in Malaysia. IManagement. Journal of Management 10(3): 29-35.

Ayinde, A. T. 2011. "Mediating role of psychosocial factors on the relationship between downsizing and employees' commitment to work among federal civil servants in Nigeria". Journal of Management and Strategy, Vol. 2(3): 2-12.

Atwood, J., Coke, E., Cooper, C., and Loria, K. 1995. "Has downsizing gone too far?" University of North Florida, MBA Research Project 6056, Jacksonville FL.

Badshah, A. 2007. Attribution theory in Ritzer (ed.): 205-7

Bagby, James W. 1957. "Dominancein binocular rivalry in Mexico and the United States". Journal of Abnormal and Social Psychology 54: 331-334.

Barasa, L., Knoben, J., Vermeulen, P., Kimuyu, P., and Kinyanjui, B. 2017. "Institutions, resources and innovation in East Africa: a firm level approach". Resource Policy 46: 280-291. https://doi.org/10.1016/j.respol.2016.11.008

Bashford, S. 2004. "The survivor syndrome”. Human Resources 64(10): 43-44.

Blunt, P., and Jones, M. L. 1992. Managing organisations in Africa. De Gruyter: Berlin

Bond, M. H., and Smith, P. B. 1996a. "Cross-cultural social and organizational psychology". Annual Review of Psychology 47:205-235.

Bordia, P., Restubog, S.L.D., and Tang, R.L. 2008. "When employees strike back: Investigating mediating mechanisms between psychological contract breach and workplace deviance". Journal of Applied Psychology 93(5): 1104-1117.

Boyatzis, R. 1998. Transforming qualitative information: Thematic analysis and code development. London, Sage Publication Ltd. 
Bryman, A. 2008. Social research methods. Oxford, Oxford University Press.

Budros, A. 1999. "A conceptual framework for analysing why organisations downsize". Organisation Science. 10(1): 69-82.

Bujang, S., and Sani, N. 2014. Downsizing Effects on Survivors. In 11th International Conference on Human Resource Development on Research and Practice. Malaysia. Retrieved from http://www.textroad.com/pdf/JBASR/J. Basic. Appl. Sci. Res., 4(5):105-115, 2014.pdf

Buono, A. F. 2003. "The hidden costs and benefits of organisational resizing activities" In resizing the organisations: Managing layoffs, divestitures, and closings, (eds) K.P De Meuse and M.L. Marks. San Francisco. CA: Jossey-Bass, 306-346.

Burnes, B. 2000. Managing change: A strategic approach to organisational dynamics. London: Pitman.

Central Bank of Nigeria (CBN). 2009. The current global financial crises: Antecedents, causes, effects and implications for Nigerian economy: A presentation by research department of CBN at global financial crises seminar, Abuja, Nigeria.

Central Bank of Nigeria (CBN). 2010. Statistical Bulletins of 2010, Abuja. Central Bank Publication.

Chaudhry, A., Coyle-Shapiro, J.A-M., and Wayne, S. J. 2011. "A longitudinal study of the impact of organisational change on transactional, relational and balanced psychological contracts". Journal of Leadership and Organisational Studies 18:247-259.

Cameron, K.S. 1994. "Strategies for successful organisational downsizing". Human Resource Management 33(2): 189-211.

Cartwright, S. 2008. Mergers and acquisitions: Why 2+ 2 does not always make 5. In J Barling\& C.L Cooper (ed.). Handbook of Organisational Behaviour, 583-601. Los Angeles, CA: Sage.

Cascio, W. F., and Young, C E. 2003. Financial consequences of employment change decisions in major US corporations, 1982-2000. In K P. De Meuse and M L. Marks (Eds.), resizing the organisation: managing layoffs, divestiture, and closing. 131-156, San Francisco: Jossy-Bass.

Chang, C. 2018. "Psychological contract breach and citizenship behaviour: A thwarted need to control perspective". Presented at annual meeting of the academy of management, Chicago, Aug. 10-14.

Chen, Z.X., Tsui, A.S., and Zhong, L. 2008. "Reactions to psychological contract breach: A dual perspective”. Journal of Organisational Behaviour 29: 527-548.

Coyle-Shapiro, J. A., Costa, S. P., Doden, W., and Chang, C. 2019. "Psychological contracts: Past, present, and future". Annual Review of Organizational Psychology and Organizational Behaviour 6(1): 145-169.

Coyne, I. M. 2008. "Sampling in qualitative research". Purposeful and theoretical sampling; merging or clear boundaries? Journal of Advanced Nursing 26(3): 623-630.

Creswell, J. W. 2003. Research design. Qualitative, quantitative and mixed methods approaches. second edition, Sage Publications.

Cropanzano, R., Rupp, D. E., and Byrne, Z. S. 2003. "The relationship of emotional exhaustion to work attitudes, job performance and organisational citizenship behaviours". Journal of Applied Psychology 88(1): 160-169.

Cullinane, N. and Dundon, T. 2006. "The psychological contract: A critical review". International Journal of Management Review 8 (2): 113-129. 
Dadi, V. 2012. “The black British clerical workers' response to psychological contract violation". International Journal of Human Resource Management and Research 2(4): 67-80.

Datta, D.K., Guthrie, J.P., Basuil, D., and Pandey, A. 2010. "Causes and effects of employee downsizing: A review and synthesis". Journal of Management 36(1): 281-348.

Davis-Peccoud, J., Stone, P., and Tovey, C. 2016. Achieving breakthrough results in sustainability. Bain \& Company. Retrieved from http://www.bain.com/publications/articles/achieving-breakthrough-results-insustainability.aspx.

Day, N.E. 2005. "Religion in the workplace: correlates and consequences of individual behaviour". Journal of Management, Spirituality \& Religion 2(1): 104-135.

Delery, J. E., and Roumpi, D. 2017. "Strategic human resource management, human capital and competitive advantage: Is the field going in circles?" Human Resource Management Journal 27(1): 1-21.

Diaz-Fernandez, M., Pasamar-Reyes, S., and Valle-Cabrera, R. 2017. "Human capital and human resource management to achieve ambidextrous learning: A structural perspective". Business Research Quarterly 20(1): 63-77.

Dicicco-Bloom, B., and Crabtree, B. 2006. The qualitative research interview. Available online at https://www.ncbi.nlm.nih.gov/pubmed/16573666

Dixon-Fowler, H., Slater, D., Johnson, J., Ellstrand, A., and Romi, A. 2013. "Beyond "does it pay to be green?": A meta-analysis of moderators of the CEP-CFP relationship". Journal of Business Ethics 112(2): 353-366.

Ehnert, I., and Brandl, J. 2013. Towards a paradox perspective for HRM: Integrating research and moving ahead, unpublished paper presented at the 28th EIASM Workshop on Strategic HRM, 14-15 April. Copenhagen, Denmark.

Erez, Miriam, and Earley, Christopher .P. 1993. Culture, self-identity and work. New York: Oxford University Press.

Farwell, R.M. 2007. The effects of globalisation and corporate downsizing on employee health. Lakehead University Canada: ProQuest LLC.

Fajana, S. 2009. "Human resource management in Africa: The social and economic framework". Personalfuhrung 7: 80-86.

Fajana, S., Owoyemi, O., Elegbede, T., and Gbajumo-Sheriff, M. 2011. "Human resource practice in Nigeria". Journal of Management and Strategy 2(2): 57-62.

Fieulaine, N., and Apostolidis, T. 2015. "Precariousness as a time horizon: How poverty and social insecurity shape individuals' time perspectives". In M. Stolarski, N. Fieulaine, \& W. van Beek (Eds.), Time perspective theory; Review, research and application: Essays in honour of Philip G. Zimbardo (213-228). Springer International Publishing. https://doi.org/10.1007/978-3-319-07368-2_14.

Fiske, Susan T. and Shelley Taylor, E. 1984. Social cognition. Reading MA: AddisonWesley.

Fong, K., and Kleiner, B. H. 2004. "New development concerning the effect of work overload on employees". Management Research News 27 (4/5): 9-16.

Fongwa, M. N. 2002. "International healthcare perspectives: The Cameroon example". Journal of Trans-cultural Nursing Vol. 13(4): 325-330. 
Frankel, B., and Hewitt, W.E. 1994. "Religion and well-being among Canadian university students: the role of faith groups on campus". Journal for the Scientific Study of Religion 33(1): 62-73.

Gandolfi, F. 2007. "How do large Australian and Swiss Banks implement downsizing?" Journal of Management Organisation 13(2): 145-159.

Fortune 2018. 100 best companies to work. In T. L. Friedman (Ed.). 2005. The World Is Flat: a brief history of the twenty-first century. New York: Farrar, Straus and Giroux.

Godard, J. 2004. "A critical assessment of the high performance paradigm". British Journal of Industrial Relations 42(2): 349-378.

Grunberg, L., Moore, S., and Greenberg, E. 2001. "Differences in psychological and physical health among layoff survivors: The effect of layoff contact". Journal of Occupational Health Psychology 6(1):15-25.

Guest, D., and Conway, N. 2002a. "Communicating psychological contract; employer perspective". Human Resources Management Journal 12(2): 22-38.

Guest, G., Namey, E. E., Mitchell, M. L. 2013. Collecting qualitative data: A field manual of applied research. Gray Insight Research. Sage.

Guerci, M., and Pedrini, M. 2014. "The consensus between Italian HR and sustainability managers on HR management for sustainability-driven change - towards a 'strong' HR management system”. International Journal of Human Resource Management, 25(13): 1787-1814.

Hitt, M. A., Keats, B.W., Harback, H.F., and Nixon, R, D. 1994. "Rightsizing: building and maintaining strategies, leadership and long- term competitiveness". Organisational Dynamics 23(2): 18-32.

Hofstede, G. 1983. Dimensions of national culture in fifty countries and three regions. In J.B. Deregowski, S. Dziurawiec and R.C. Annis (ed.), Explications in Cross-Cultural Psychology, 335-355. Lisse; Swets \& Zeitlinger

Hofstede, G. 2001. Culture's consequences: Comparing values, behaviours, institutions and organisations across nations ( $2^{\text {nd }}$ ed.). Thousand Oaks, CA: Sage Publications

Hossain, M. 2018. "Frugal innovation: A review and research agenda". Journal of Cleaner Production 182: 926-936. https://doi.org/10.1016/j.jclepro.2018.02.091

Huzaifah bin Magbool, M. A., Amran, A., Nejati, M., and Krishnaswamy, .J. 2016. "Corproate sustainable business practices and talent attraction". Sustainability Accounting, Management and Policy Journal 7(4): 539-559.

Jackson, T. (2002). "Reframing human resource management in Africa: A cross-cultural perspective". International Journal Human Resource Management 13(7): 998-1018.

Jackson, T. 2002. "The management of people across cultures: Valuing people differently". Human Resource Management Journal 41(4):455-475.

Jones, D. A., Willness, C., and Madey, S. 2014. "Why are job seekers attracted by corporate social performance? Experimental and field tests of three signal-based mechanisms". Academy of Management Journal 57(2): 383-404.

Jones, S. K., and Griep, Y. 2018. "I can only work so hard before I burn out". A time sensitive conceptual integration of ideological contract breach, work effort, and burnout. Frontiers in Psychology 9(31): 1-14.

Kessapidou, S., and Varsakelis, N. C. 2002. "The impact of national culture on international business performance: The case of foreign firms in Greece". European Business Review 14(4): 268-275. 
Karim, S., and Kaul, A. 2015. "Structural recombination and innovation: unlocking Intraorganizational knowledge synergy through structural change". Organisational Science. 26(2): 439-455. https://doi.org/10.1287/orsc.2014.0952.

Kawai, N. 2015. "Does downsizing really matter? Evidence from Japanese multinationals in the european manufacturing industry". International Journal Human Resource Management 26(4): 501-519. https://doi.org/10.1080/09585192.2011.616525.

Kamoche, K. 1997. "Competence creation in the African public secto"r. International Journal of Public Sector Management 10(4): 268-278.

Kamoche, K. 2000. "Boom to burst: The challenges of managing people in Thailand". International Journal of Human Resource Management 11(2): 452-468.

Kramar, R. 2014. "Beyond strategic human resource management: Is sustainable human resource management the next approach?" The International Journal of Human Resource Management 25(8): 1069-1089.

Kirkman, B. L., Lowe, K. B., and Gibson, C. B. 2006. "A quarter century of cultural consequences: A review of empirical research incorporating Hofstede's cultural values framework". Journal of International Business Studies 37(3): 285-320.

Kim-Prieto, C., and Diener, .E. 2009. "Religion as a source of variation in the experience of positive and negative emotions". The Journal of Positive Psychology 4(6): 447-460.

Knights, J. A., and Kennedy, B.J. 2005. "Psychological contract violation: Impacts on job satisfaction and organisational commitment among Australian senior public servants". Applied HRM Research 10(2): 27-72.

Kurucz, E. C., Colbert, B. A., Lüdeke-Freund, F., Upward, A., and Willard, B. 2017. Relational leadership for strategic sustainability: Practices and capabilities to advance the design and assessment of sustainable business models. Journal of Cleaner Production 140(1): 189-204.

Kulkarni, V. V. 2008. "How does downsizing affect survivors? Insights from the literature". Management and Labour Studies 33(2): 241-259.

Lester, S. W., Kickul, J.R., and Bergmann, T. J. 2007. "Managing employee perceptions of psychological contract over time: The role of employer social accounts and contract fulfilment”. Journal of Organisational Behaviour 28(2): 191-208.

Lester, S.W., Turnley, W. H., Bloodgood, J.M., and Bolino, M.C. 2002. "Not seeing eye to eye: Differences in supervisor and subordinate perceptions of and attributions of psychological contract breach". Journal of Organisational Behaviour 23(1): 39-56.

Levinson, H., Price, C. R., Munden, K. J., Mandl, H. J., and Solley, C. M. 1962. Men, management and mental health. Cambridge, MA. Harvard University Press.

Lindorff, M., Worrall, L. and Cooper, C. 2011. "Managers' well-being and perceptions of organisational change in the UK and Australia". Asia Pacific Journal of Human Resources 49 (2): 233-254.

Lincohn, Y. S., and Guba, E. 1985. Naturalistic inquiry. Beverly Hills, CA:Sage.

Longoni, A. 2014. Sustainable operations strategies: The impact of human resource management and organisational practices on the triple bottom line. Nueva York (United States of America):Springer,08/201452 Springer Briefs in Applied Sciences and Technology. SpringerBriefs:Springer (PoliMI).

Littler, C.R., Dunford, R., Bramble, T., and Hede, A. 1997. "The dynamics of downsizing in Australia and New Zealand". Asia Pacific Journal of Human Resources 35(1): 65-79. CrossRef | Google Scholar 
Lytle, Anne M., Jeanne M. Brett., Zoe .I. Barsness., Catherine .H.Tinsley and Maddy Janssens. 1995. "A paradigm for confirmatory cross- cultural research in organizational behaviour in Research in organizational behaviour". L.L. Cummings and B. M. Staw (eds).Vol.17. Greenwich,CT: JAI Press.

Mason, J. 1996. Qualitative researching. London, Saga Publication.

Macredie, R. D., and Mijinyawa, K. 2011. A theory -grounded framework of open source software adoption in SMEs. European Journal of Information Systems 20(1): 237-250.

Markus, Hazel Rose and Shinobu Kitayama .1991. "Culture and the self: Implications for cognition,emotion and motivation". Psychological Review 98(2): 224-253.

Mbigi, L. 1997. Ubuntu: The African dreams in management. Randbury [South Africa]. Knowledge Resources.

Miller, Joan G., David .M. Bersoff and Robin, L. Harwood .1990. "Perceptions of social responsibilities in India and the United States: Moral imperatives or personal decisions". Journal of Personality and Social Psychology 58(1): 33-47.

McCann, L, Morris, J., and Hassard, J. 2008. "Normalised intensity:The new labour process of middle management". Journal of Management Studies 45: 343-371.

Miles, M. B. And Huberman, A. M. 1994. Qualitative data analysis: An expanded sourcebook. Thousand Oaks. California: Sage Publication Ltd.

Mishra, A. K., and Spreitzer, G. M. 1997. Explaining how survivors respond to downsizing: The role of trust, empowerment, and justice. And work design. Working Paper. Michigan State University.

Munoz-Bullon, F., and Sanchez-Bueno, M. 2011. "Does downsizing improve organisational performance? An analysis of Spanish manufacturing firms". The International Journal of Human Resource Management 22(14): 2924-2945.

Nelson, D. 2009. "Feeling good and open-minded: The impact of positive effect on cross cultural empathic responding". The Journal of Positive Psychology 4(1): 53-63.

Noer, D.M. 1993. Healing the wounds: Overcoming the trauma of layoffs and revitalizing downsizing organisations. San Francisco: Jossey-Bass.

Oluba, M. N. 2008. Basic thoughts of revising the trends of financial exclusion in Nigeria. Retrieved n.d. from http//www.martinoluba.com, Vol. (B):21.

Olurode, L. 1994. Nigerian heritage. Lagos: Rebonik Publications Ltd.

Omoruyi, Q., Chipunza, C., and Samuel, M. O. 2011. "Perceptions of justice and extra-role behaviours of survivors after organisational restructuring at a consolidated bank in Nigeria". SA Journal of Human Resource Management 9(1): 1-14.

Omonzejele, P. F. 2008. "African concepts of health, disease, and treatment: An ethical inquiry". Journal of Science and Healing Vol. 4(2): 120-126.

Pansera, M., and Owen, R. 2018. "Framing inclusive innovation within the discourse of development: insights from case studies in India". Resource Policy 47: 23-34. https://doi.org/10.1016/j.respol.2017.09.007.

Pelled, Lisa Hope and Katherine, .R.Xin .2000. "Relational demography and relationship quality in two cultures". Organization Studies, 21(6):1077-1094.

Perssona, S., and Wasieleski D.2019. "The seasons of the psychological contract: Overcoming the silent, transformations of the employer-employee relationship". Human Resource Management Review 25 (2015): 368-383.

Prieto, I., and Perez-Santana, I. 2014. "Managing innovative work behaviour: The role of human resource practices". Personnel Review 43(2): 184-208. 
Ren, T., and Jackson, S. E. 2018. "Green human resource management research in emergence: A review and future directions". Asia Pacific Journal of Management 35(3):769-803.

Raja, U., Johns, G. and Ntalianis, F. 2004. The impact of personality on psychological contracts'. Academy of Management Journal 47(3): 350-367.

Restubog, S.L.D., Bordia, P., and Tang, R. L. 2006. "Effects of psychological contract breach on performance of IT employees: the mediating role of affective commitment". Journal of Occupational and Organisational Psychology 79(2): 299-306.

Restubog, S.L D., Bordia, P., and Tang, R. L. 2007. Behavioural outcomes of psychological contract breach in a non-western culture: The moderating role of equity sensitivity, British Journal of Management Vol. 18(4):376-386.

Restubog, S. L. D., Hornsey, M. J., Bordia, P., and Esposo, S. R. 2008. "Effects of psychological contract breach on organisational citizenship behaviour: Insights from the group value model". Journal of Management Studies 45 (8): 1377-1400.

Rousseau, D. 1989. "Psychological and implicit contracts in organisations". Employee Responsibilities and Rights Journal 2( 2): 121-139.

Rousseau, D. 1995. Psychological contracts in organisations: Understanding written and unwritten agreements. Thousand Oaks, CA: Sage.

Rousseau, D. 1998. The 'problem' of psychological contract considered. Journal of Organisational Behaviour, 19: 665-672.

Rousseau, D. M., and Schalk, R. 2000. Psychological contract in employment: A crossnational perspectives. Thousand Oaks, CA: Sage.

Samuel, M. O., Osinowo, H. O., and Chipunza, C. 2009. "The relationship between bank distress, job satisfaction, perceived stress and psychological well-being of employees and depositors in Nigeria banking secto"r. African Journal of Business Management 3(11): 624-632.

Sanusi, S. L 2011. The impact of the global financial crises on the Nigerian capital market and the reforms: A paper presented at the $7^{\text {th }}$ annual pearl awards and public lecture, Muson Centre Lagos, May $27^{\text {th. }}$

Sanz-Valle, R., and Jimenez, D. 2018. "HRM and product innovation: Does innovative work behaviour mediate such relationship?" Management Decision 56(6): 1417-1429.

Sahdev, K. 2003. "Survivors' reactions to downsizing: The importance of contextual factors". Human Resource Management Journal 13(4): 56-74.

Sahay, Sundeep and Geoff, Walsham. 1997. "Social structure and managerial agency in India". Organization Studies 18(3): 415-444.

Sels, L., Janssens, M., and Van den Brande, I. 2004. "Assessing the nature of psychological contracts: A validation of six dimensions". Journal of Organizational Behaviour. 25(4): 461-488.

Shipton, H., Sparrow, P., Budhwar, A., and Brown, A. 2017. "HRM and innovation: Looking across levels". Human Resource Management Journal 27(2): 246-263.

Sparrow, P., and Cooper, C.L. 1998. "New organisational forms: The strategic relevance of future psychological contract scenarios". Canadian Journal of Administrative Sciences 15(4): 356-371.

Sparrow, P. 1998b. "Re-appraising psychological contracting: Lessons for employee development from cross-cultural and occupational psychology research". International Studies of Management and Organisation 28(1): 30-63. 
Spreitzer, G. M., and Mishra, A. 1997. Survivor Responses to Downsizing: The Mitigating Effects of Trust and Empowerment. South California Studies Centre. University of South California. September 1.

Sronce, R., and McKinley, W. 2006. "Perceptions of organisational downsizing". Journal of Leadership and Organisational Studies 12(1):89-108.

Suazo, M. M. 2009. "The mediating role of psychological contract violation on the relationship between psychological contract breach and work-related attitudes and behaviours". Journal of Management Psychology 24(2): 136-160.

Schwandt, T. A. 1997. Qualitative inquiry: A dictionary of terms. Thousand Oaks, CA: Sage.

Shore, L. M., Tetrick, L. E., Taylor, S. M., Coyle Shapiro, JA-M., Liden, R. C., McLean Parks, J., Wolfe Morison, E., Porter, L. W., Robinson, S. L., Roehling, M. V., Rousseau, D. M., Schalk, R., Tsui, A. S., and Van Dyne, L. 2004. "The employee-organization relationship: A timely concept in a period of transition". In J. J. Martocchio (Ed.). Research in Personnel and Human Resources Management (pp. 291-370). Elsevier/JAI Press.

Tang, G., Chen, Y., Jiang, Y., Paillé, P., and Jia, J. 2018. "Green human resource management practices: Scale development and validity". Asia Pacific Journal of Human Resources 56(1): 31-55.

Teklab, A.G., and Taylor, M.S. 2003. “Aren't there two parties in an employment relationship? Antecedents and consequences of organisation-employee on contract obligations and violations". Journal of Organisational Behaviour 24: 585-608.

Thomas, D. C., Au, K., and Ravlin, E. C. 2003. "Cultural variation and psychological contract Violations". Journal of Organisational Behaviour 24: 451-471.

Ting-Toomey, Stella.1988. “A face-negotiation theory”.in Theory in intercultural lcommunication". Y. Y. Kim and W. B. Gudykunst (eds). Newbury Park, CA:Sage.

Tiwari B., and Lenka U. 2019. "Employee engagement: A study of survivors in Indian IT/ITES sector". IIMB Management Review (2019), doi: https://doi.org/10.1016/j.iimb.2019.10.003

Trevor, C. O., and Nyberg, A. J. 2008. "Keeping your headcounts when all about you are losing theirs: Downsizing, voluntary turnover rates, and the moderating role of HR practices". Academy of Management Journal, 51(2): 259-276.

Triandis, H. C. 1995. Cross-cultural studies of individualism and collectivism. Boulder, CO: Westview .

Uchenna, C.O. 2015. "Psychological Contract Experience of Survivor First-line Managers during Organisational Downsizing: The Mediating Influence of Culture in Nigeria". MPhil Thesis. Department of Management and Business Systems, Business and Management Research Institute, University of Bedfordshire.

Vincente-Lorente, J. D., and Suarez-Gonzalez, I. 2007. "Ownership traits and downsizing behaviour: Evidence for the largest Spanish firms". 1990-1998, Organisation Studies, 28(11): 1613-1638.

Washington, M., and Hacker, M. 2005. "Why change fails: Knowledge counts". Leadership and Organisational Development Journal, 26:400-411.

Westwood, R., Sparrow, P., and Leung, A. 2010. "Challenges to the psychological contract in Hong Kong”. The International Journal of Human Resource Management 12 (4): 621651. 
William, J. E., Satterwhite, R. C., and Saiz, J. L. 1998. The importance of psychological traits: A cross-cultural study. New York, NY: Plenum Press.

Wolfe Morrison, E., and Robinson, S.L. 1997. "When employees feel betrayed: a model of how psychological contract develops". Academy of Management Review, 22 (1): 226231.

Woodgate, R. L. 2006. "Living in a world without closure: Reality for parents who have experienced the death of a child". Journal of Palliative Care, 22(2): 75-82.

Wright, P. M., and Ulrich, M. D. 2017. "A road well travelled: The past, present, and future journey of strategic human resource management". Annual Review of Organizational Psychology and Organizational Behavior 4: 45-65.10.1146/annurev-orgpsych032516- 113052 [Crossref], [Google Scholar]

Yu, G. and Park, J. 2006. "The effects of downsizing on the financial performance and employee productivity of Korean firms". International Journal of Manpower 27(3): 230-250.

Zhao, H, Wayne, S.J., Glibkowski, B.C., and Bravo, J. 2007. "The impact of psychological contract breach on work-related outcomes: A meta-analysis". Personnel Psychology 60(3): 647-680. 